\section{ENTRE LA RUTA Y EL BARRIO: LA EXPERIENCIA DE LAS ORGANIZACIONES PIQUETERAS}

Maristella Svampa y Sebastián Pereyra

Buenos Aires: Biblos, 2003. 230p.

\section{Javier Ghibaudi, Ippur (UFRJ)}

Junto com a recente eclosão da crise socioeconômica na Argentina, ganha visibilidade um amplo conjunto de açôes coletivas de protesto social. Associadas a setores sociais particularmente afetados pela crise e apresentando-se como organizaçóes de desempregados, destacam-se ali as chamadas organizaçóes piqueteras, hoje em dia uma referência constante no debate político argentino.

O objetivo do livro de Maristella Svampa e Sebastián Pereyra ${ }^{1}$ é o de reconstruir e analisar o conjunto destas organizações "desde suas origens, mostrando a heterogeneidade, a riqueza e a pluralidade em seu interior" (p.11-2). Trata-se de uma escolha duplamente interessante. Por um lado, pela possibilidade de se ganhar compreensão deste fenômeno social e do processo socioeconômico argentino da última década, em que se deu seu desenvolvimento. Por outro, como destacam seus autores, aparece como um objeto de estudo desafiante no interior das ciências sociais e dos estudos sobre os chamados movimentos sociais, visto que algumas correntes neles dominantes caracterizam seus participantes como "excluídos sociais" e, portanto, "incapazes" de articular qualquer ação coletiva.

Como eixos para esta tarefa de reconstrução, encontramos ao longo do livro uma ênfase no caráter de "ator coletivo e político" destas organizações e a importância de uma observação minuciosa do processo de sua formação e a interação entre seus participantes incluindo aqui também questôes sobre formas internas de organização do poder, gestão de recursos materiais e construção de identidades. Do mesmo modo, aparecem

1 Ambos são pesquisadores do CONICET da Argentina. Maristella Svampa é docente de instituicões como a Universidad de General Sarmiento, FLACSO e IDAES, havendo publicado livros de referência como La Plaza vacía. La transformación del peronismo (1997) e Desde abajo. La transformación de las identidades sociales (2000). Sebastián Pereyra é pesquisador do Instituto Gino Germani da Universidad de Buenos Aires, e destaca-se por sua producão, junto com Federico Schuster, sobre o protesto social na Argentina na última década. duas chaves de leitura que se articulam nestes eixos. Por um lado, a análise de sua relação com a dinâmica socioeconômica e política argentina mais ampla. Por outro, o estudo da articulação entre o processo de formação das organizações piqueteras e sua dimensão territorial. Com relação à primeira, os autores fazem uma constante referência a um processo de "descoletivização" e desestruturação da sociedade salarial argentina, seguindo os conceitos de Robert Castel e considerando-os pertinentes para descrever o momento histórico concreto da Argentina nas últimas décadas - sustentados para tanto em uma extensa e muito interessante base bibliográfica. Com a segunda, sublinham a importância do "processo de inscrição territorial das classes populares" (p.9) para compreender as ações coletivas que entre elas surgiriam.

No primeiro capítulo analisam a gênese do movimento piquetero, caracterizado como "movimento de movimentos". Nele se distinguem duas vertentes que inspiram o título do livro. Uma associada à "via" que agrega a série de piquetes - interrupção de vias - e puebladas - manifestação da maioria da população em seu apoio - que surgem no interior do país nos anos de 1996 e 1997. Elas dão-se em localidades estruturadas em torno de empresas estatais em processo de privatização, destacando-se o caráter multissetorial dos conflitos. Há ainda a vertente que os autores identificam com o "bairro", por ter uma "matriz especificamente territorial de ação coletiva", que ganha visibilidade também no biênio 1996-1997, especialmente na periferia da área metropolitana de Buenos Aires (p.17-8). Diferentemente da primeira, esta vertente pertenceria a uma "tradição contestatória mais ligada ao trabalho no espaço do bairro e à gestão das necessidades básicas" (p.18) tendo influência direta de sujeitos e organizaçôes vinculadas à luta pela terra e à provisão de serviços públicos nas décadas de 1970 e 1980 . Para os autores, então, a primeira vertente representa o momento de articulação do movimento, em que "uma nova identidade - os piqueteros -, uma nova forma de protesto - a interrupção de vias -, uma nova modalidade organizativa - a assembléia -, e um novo tipo de demanda - o trabalho - ficam definitivamente associados, originando uma importante transformação nos repertórios de mobilização da sociedade argentina" (p.23), influenciando e caracterizando assim a trajetória posterior do conjunto das organizaçóes piqueteras. 
Já no Capítulo 2, se analisa a segunda etapa da mobilização depois deste biênio constitutivo, tendo agora como chave de leitura explícita e quase dominante sua dimensão política. Assim, são apontadas as diferentes configurações que vão se formando entre as organizações piqueteras em sua relação com o Estado, seus discursos e diagnósticos sobre a realidade do país e seus diferentes projetos de ação. Desta maneira, os autores realizam uma primeira classificação onde distinguem três grandes linhas: a) uma caracterizada pela organização de tipo "sindical", seu caráter de "massa", sua escala nacional e sua maior institucionalização; b) uma linha "política", assim entendida por seu alto nível de confrontação com os distintos governos e sua matriz político-partidária de militância; e c) uma linha "territorial", que se delineia por rechaçar toda participação no âmbito eleitoral e reivindicar a centralidade do trabalho local-territorial. Do mesmo modo, se analisa a relação entre as organizações e os distintos governos nacionais a partir da implementação dos chamados "planos sociais" - formados por transferências monetárias para desempregados. Aqui, destaca-se como os planos fazem parte de um modelo mais amplo de intervenção do Estado no social, caracterizado agora pela focalização e a descentralização. Por sua vez, observam como em sua implementação interagem diferentes lógicas e objetivos, tanto entre os distintos níveis governamentais como entre as organizações e seu âmbito territorial - sublinhando como as organizaçóes piqueteras conseguem colocar-se como uma instância de poder quando administram seus próprios planos, conferindo-lhes novos significados pois em seu discurso aparecem como um "direito", produto "da luta coletiva”. Neste processo, ademais, os autores indicam que um "modelo de intervenção territorial" apareceria reforçado no conjunto das práticas das organizaçôes, tanto pela articulação da demanda dos planos sociais como por sua gestão a partir de um trabalho de tipo "comunitário".

O Capítulo 3, um estudo de caso, aprofunda as questôes até então apresentadas. São reconstruídas e comparadas duas experiências do movimento piquetero: a da Plaza Huincul-Cutral Có, na Patagonia argentina, e a de General Mosconi-Tartagal, na região noroeste. Destaca-se aqui que, em que pese associar-se o surgimento de ambas à dissolução do "mundo ypefeano" - em referência à antiga empresa petroleira estatal YPF -, as ações coletivas ali em formação apresentam trajetórias bem diferentes. Enquanto na primeira o conflito acabaria sendo "absorvido pelas instituições" (p.148), na segunda, a principal organização piquetera alcançaria um alto nível de autonomia e poder efetivo em seu território. Assim, a partir do controle dos planos sociais, conseguiria a articulação de uma verdadeira rede de empreendimentos que se apresentam como autogestores, responsável inclusive pela provisão de serviços comunitários, ao mesmo tempo que desenvolveria um discurso de recriação da "cultura do trabalho legítimo", constituindo-se em uma referência para diversos setores da comunidade.

Num último momento, as organizaciones piqueteras são tratadas na heterogeneidade de seus participantes, dos setores sociais a que pertenceam, de sua trajetória prévia de ação na esfera pública e do modo como foram afetados pela dinâmica socioeconômica e política mais ampla. É a partir da presença de ditos sujeitos no contexto de crise das instituiçôes político-sindicais tradicionais e de reestruturação do mundo laboral que se tenta compreender três de suas características fundamentais: seu caráter assembleário, a importância do trabalho autogerido e a relevância de seu modelo de organização territorial.

Em poucas palavras, o trabalho de Svampa e Pereyra oferece uma excelente aproximação da dinâmica socioeconômica e política argentina da última década, sem cair em teorias economicistas e mecânicas da ação coletiva, rebatidas explicitamente e com êxito, graças ao desenvolvimento de diferentes e bem articulados níveis de análise sobre um variado conjunto de experiências nas quais é clara a relevância da dimensão territorial para a análise da dinâmica social. 